UDK: 004:378

\author{
Olena G. Glazunova \\ Doctor of Pedagogical Sciences, Dean of the Faculty of Information Technology \\ National University of Life and Environmental Sciences of Ukraine, Kyiv, Ukraine \\ ORCID 0000-0002-0136-4936 \\ o-glazunova@nubip.edu.ua
}

Tetiana V. Voloshyna

assistant of information and distant technologies

National University of Life and Environmental Sciences of Ukraine, Kyiv, Ukraine

ORCID 0000-0001-6020-5233

t-voloshina@nubip.edu.ua

Nataliia Dorosh

Microsoft Ukraine, Kyiv, Ukraine

ORCID 0000-0003-4934-6814

nadorosh@microsoft.com

\title{
DEVELOPMENT OF PROFESSIONAL AND SOFT SKILLS OF FUTURE IT SPECIALISTS IN COOPERATION WITH LEADING IT COMPANIES
}

\begin{abstract}
The problem of technological universities lagging behind the level of development of the IT-industry can be solved only on condition that technological IT companies actively participate in training of future IT-professionals. Only cooperation between IT-companies and ITfaculties can provide effective training of future IT-professionals. Universities require access to new technologies in order to support students and teachers of STEM-faculties, so that they would keep up with the level of technology development. The article analyzes the trends of cooperation between universities and IT companies. For example, the integration of Microsoft resources and services into the University e-learning environment identified the impact of using appropriate resources for the development of professional skills and "soft skills". The present article suggests a model of integrating Microsoft resources and services into the e-learning environment.
\end{abstract}

Keywords: IT education; IT industry; on-line course; service; recourse; hard skills; soft skills.

\section{INTRODUCTION}

Training of IT-professionals for IT-industry is a rather complicated process under the conditions of dynamic changes in the field of IT-products. Universities face problems of technological lag behind the level of the development of IT-industry overall, access to new technologies, the necessity of continuous improvement of curricula and training programs.

The problem statement. The problem of technological universities lagging behind the level of development of the IT-industry can be solved only on condition that technological IT companies actively participate in training of future IT-professionals. Only cooperation between IT-companies and IT-departments can provide effective training of future ITprofessionals. Universities require access to new technologies in order to support students and teachers of STEM-faculties, so that they would keep up with the level of technology development.

IT-companies through their cooperation with universities have the opportunity to distribute their products among future IT-professionals, giving their technologies for free to Universities, generating educational and instructional materials for studies, creating a cloud environment to enable access to technologies with the ability to gain practical skills using them. In addition, a considerable number of companies are introducing the certification process for their own technologies, e.g. Microsoft, Cisco, 1C. 
The problem of the quality of training and future employment of IT graduates is the main challenge of STEM education nowadays.

Analysis of recent studies and publications. The forms of cooperation between ITcompanies and universities are quite diverse and aimed at the improvement of quality of IT education.

Both foreign and domestic scientists were involved in the study of organizational and methodological aspects of the cooperation between IT companies and universities. In particular, Y. Kryvoruchko [1] provided examples and possibilities of evaluating the effectiveness of partnerships with business partners, I. Kondratenko [2] defined the peculiarities of university cooperation in the field of information technology, H. Gogl, K. Shedler [3] conducted an analysis of cooperation between companies and universities in Europe.

Formalized models of University-Business Cooperation (UBC) have been proposed, and the first experience of such cooperation has been analyzed by V.C. Khnbarchenko, V.V. Sklar [4], [5].

In particular, the authors have identified the following main forms of cooperation between universities and business: assistance in the organization of on-the-job training, involvement of students in the work at enterprises, individual selection of young professionals on the request of an enterprise, concluding agreements on target training of IT-specialists, presentation of enterprises at universities, participation of enterprises' specialists in academic process.

StepanVeselovsky, director of the Lviv IT Cluster notices that the IT-industry requires high quality education. The creation of IoT study programs in Lviv Polytechnic University and Data Science study programs at Ukrainian Catholic University have become the evidence of this. The launched innovative study programs will determine the development of IT in the near future and will dictate the trends to other educators [6].

In December 2015 the National University of Life and Environmental Sciences of Ukraine (hereinafter referred to as NULES) and "Procom" company created a joint training lab "Competence center of $1 \mathrm{C}$ " to provide students with practical experience in real ITprojects participation and additional certificates confirming their qualification according to the selected direction which will further their employment opportunities [7].

In Lviv among the examples of cooperation between schools and real businesses there are some projects of Lviv cluster of IT and business services (Lviv IT-BPO Cluster) founded by leading companies in the field of Information Technology and Business Process Outsourcing, that together took the initiative of making systemic changes in the business environment of the city [8].

In 2012 the cluster supported the setting-up of programming laboratories for embedded and mobile platforms at the Software Department of the Institute of Computer Science and Informatics of the National University "Lviv Polytechnic".

The creation of Master program "Internet of Things" is a joint project of the Lviv Polytechnic and Lviv IT Cluster within the "IT Expert" project, the aim of which is to attract IT specialists to the training process as consultants [9].

Karazin Kharkiv National University (hereinafter referred to as KNU) is developing the curriculum for training of specialists in biostatistics (processing of large data obtained in clinical research), which is the only program in Eastern Europe of its kind where students have the opportunity to develop their skills in applied statistics and study the clinical SASprogramming on the real data, etc.

The program was developed in collaboration with Experis and Intego Group and it is available for Master students of both KNU and other Kharkiv universities - the courses are in overall university schedule. 
Most of the classes and meetings with guest speakers are held in English, all training materials are also available in English. Specialists of Experis and Intego Group are the curators of students during team projects.

At the end of the program, graduates receive not only the University diploma, but are also awarded a certificate of the Center for Biostatistical Programming. For the best students there is also a possibility to get a professional certificate of basic programming SAS, to participate in paid internships in the company and get a job as Clinical SAS Programmer.

Kharkiv National University of Radio Electronics has introduced a dual education system, with 3rd year-students working in partner companies. They study two days per week, Monday and Saturday, and are engaged in self-study. And the other 4 days a week students will work. Samsung Electronics actively cooperates with Kharkiv National University of Radioelectronics (KNURE) creating joint scientific and commercial projects, developing new educational disciplines [10].

In April 2016 within the socio-educational program "LIFECELL universities", aimed at the improvement of practical skills of students in telecom-specialities, operator Telecom LIFECELL opened a special laboratory at the Institute of Telecommunication Systems in the National Technical University of Ukraine "Igor Sikorsky Kyiv Polytechnic Institute" [7].

In September 2016 the administration of Yuriy Fedkovych Chernivtsi National University signed a cooperation agreement with IT-company AMC Bridge. AMC Bridge is a famous company with high demands to engineering training disciplines for technicians and system analysts. Such specialists are trained at the university in the majors "Computer Science", "Computer engineering" and "Software Engineering". University faculty will be able to get a real job experience in the company and share new experiences in the classroom. Students will also have practical training in AMC Bridge [11].

Such global companies - producers of IT products as Cisco and Microsoft open wide opportunities for universities. Companies of such level create their own academic clouds that include online courses, cloud services to access the practical use of the latest developments and tools for organization of training in their own technologies [12, 13, 14, 15].

The article's goal. The purpose of the article is to analyze the ways of cooperation between universities and IT companies, to justify the model of integrating resources and services of IT companies in the e-learning environment, to investigate the effect of using external resources and services for the development of professional and soft skills of future IT-professionals.

\section{THE THEORETICAL BACKGROUNDS}

Having analysed forms and ways of cooperation between Universities and IT companies we are able to summarize such cooperation (fig. 1.)

Review of sources on the topic of research of cooperation between universities and IT companies shows that the quality of IT education cannot be separated from the IT business. STEM-faculty training specialists for work in the IT-industry creates academic training programs based on the requirements for the competences of future specialists made by experts in the IT industry.

IT-industry representatives who are interested in advancing their own technologies should provide access to their technologies for educational institutions and provide teachers of educational institutions with resources and services, create conditions for the professional development of teachers. Only in such case IT education will be successful.

In terms of cooperation with Universities Microsoft offers full support of technologies being developed for distribution among users. Most developed technologies are accompanied by online course or Microsoft Virtual Academy or Imagine Academy, cloud platform for 
studying technologies such as O365, Azure and the ability to go through the MOS certification lines, MCE, MTA.

In addition, Microsoft provides many other resources to support its own technologies that envisage for every developed IT product the creation of platform for access to this product, online courses for studying the features of the product and the opportunity of professional certification for this IT product.

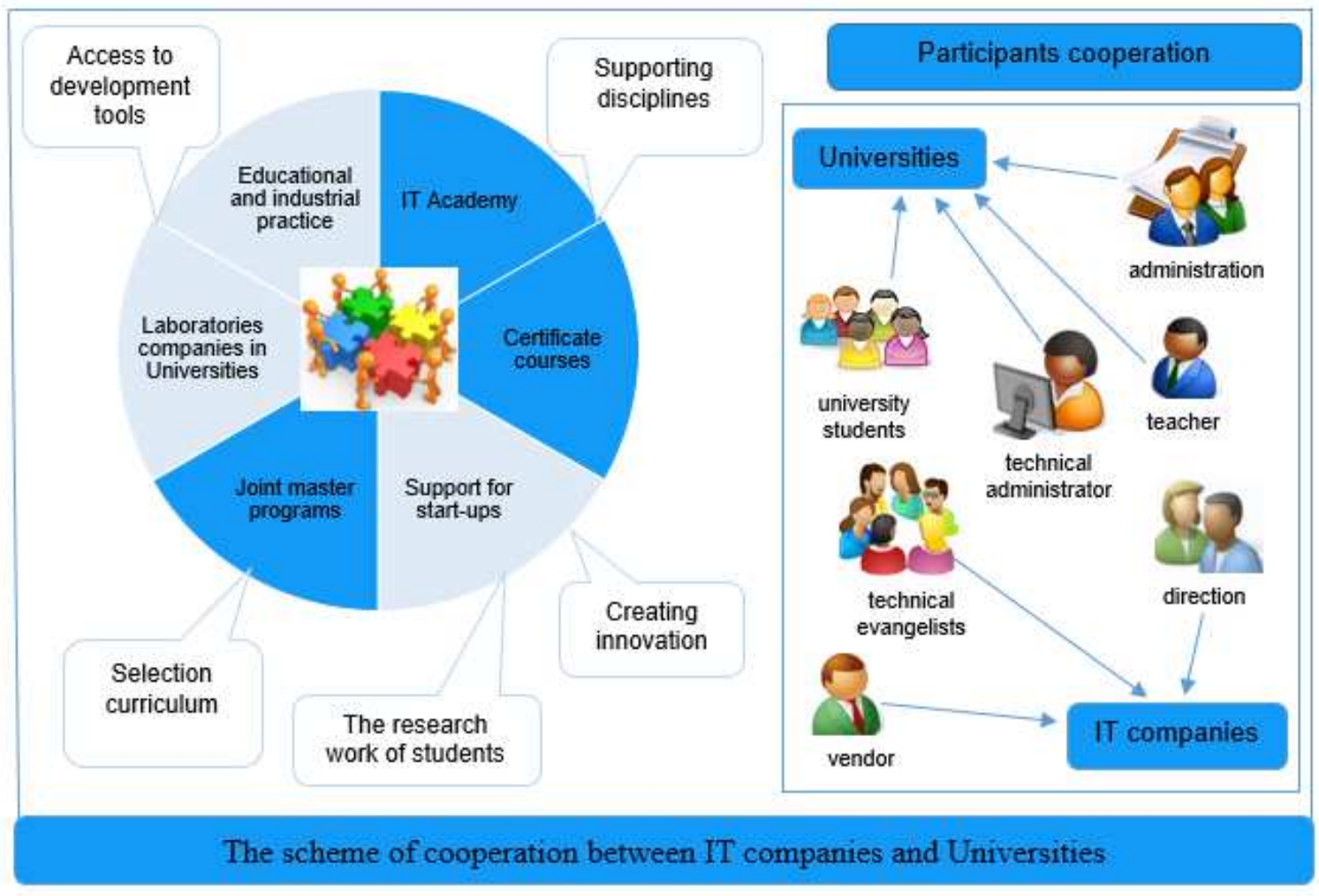

Figure 1. The scheme of cooperation between IT companies and Universities

Microsoft is one of a few companies that offer free academic resources and services for training. With the help of these resources it is possible to gain new knowledge and skills required also for career promotions.

In particular, Microsoft provides an opportunity to study such technologies as databases, programming, virtualization, duplication, server technology for training students in the IT profession.

To explore each technology Microsoft offers training resources in the form of online courses, software and cloud environment that provide practical use of software such as virtual machines - Azure Virtual Machines.

At the same time, Microsoft educational policy is to attract as many teachers of secondary, vocational and higher education institutions as it can to study modern educational technologies based on the use of ICT in education.

Microsoft resources such as: Imagine Academy, Virtual Academy, Channel9, Educator Community, Developer Network include online courses, informative educational materials for different types of users from beginners to professional software developers.

Services O365, Azure, Imagine, CodePlex and others serve as modern tools of working with the latest versions of software, software development, as well as tools of co-work with documents, communications, creation of an educational e-environment. 
In March 2016 NULES of Ukraine and Microsoft Ukraine signed an educational volume licensing Microsoft agreement and Microsoft Imagine Academy.

Thanks to this international program the gained knowledge and skills allow teachers and students to conduct certification on three lines of professional development: Microsoft Office Specialist (MOS) - getting skills in Microsoft Office; Microsoft Technology Associate (MTA) - understanding the basic technological concepts in the sphere of the development of software and information technologies; Microsoft Certified Educator (MCE) - technical literacy of a teacher.

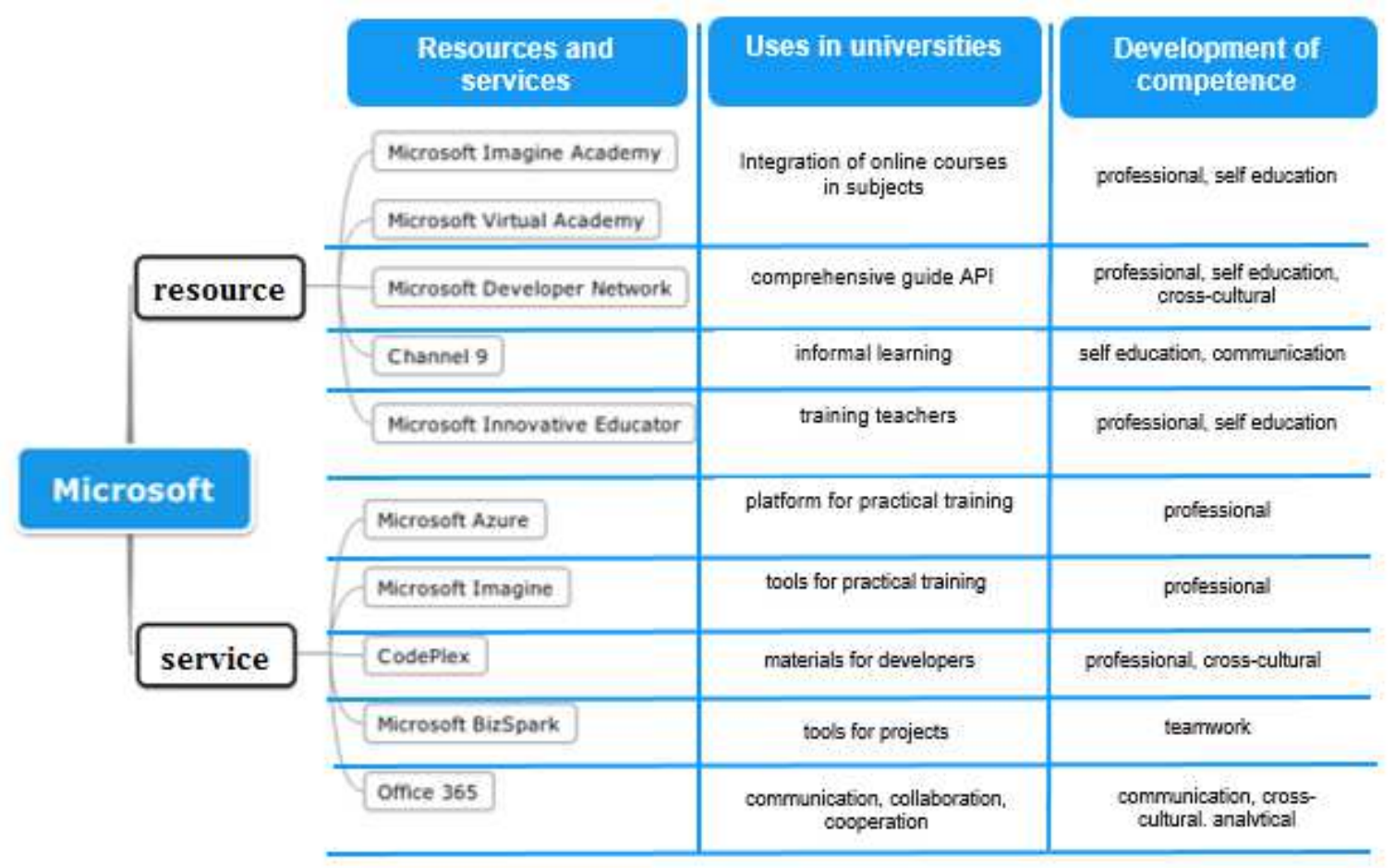

Figure 2. The use of resources and services of Microsoft in Universities

Having obtained Microsoft certification students will be able to demonstrate their knowledge and ability to use new technologies; realistically assess their knowledge and be confident in it; achieve greater success in an effort to get higher education or get a job; gain recognition among colleagues and employers and a clear advantage in competitive labor market; plan in-service education to obtain knowledge of Microsoft on a higher level.

Microsoft has developed the program called Microsoft Imagine, which provides students with free access to design tools and software development. Through this program, students have access to resources that provide practical work and help master their skills to the level required today on labor market. Imagine).

Universities across Ukraine have established over 40 IT Academies (Microsoft

\section{THE RESULTS AND DISCUSSION}

The experiment of using Microsoft academic resources and services has been running for 2 years in NULES. The main results of collaboration lie in systematic work with the resources and services available through academic initiatives of Microsoft with the aim to develop professional and soft skills of future IT-professionals in the following areas: 
integration of academic resources in the curricula, the use of services for organizing the academic process, professional development of academic faculty, promotion of up-to-date technologies in seminars and trainings by Microsoft trainers, professional certification programs for teachers and students (fig.3).

The pedagogical experiment of integration of Microsoft academic resources into academic disciplines for training IT specialists was conducted by using online courses of Imagine Academy and Virtual Academy as necessary during the study of specified disciplines.

In NULES of Ukraine some online courses of Imagine Academy are integrated into academic disciplines studied by students of different majors. In particular, for students majoring in IT such disciplines as "Information Technology", "Programming", "Organization Database" were supplemented with individual tasks for self-study on Imagine Academy online courses (https://imagineacademy.microsoft.com/?whr=default).

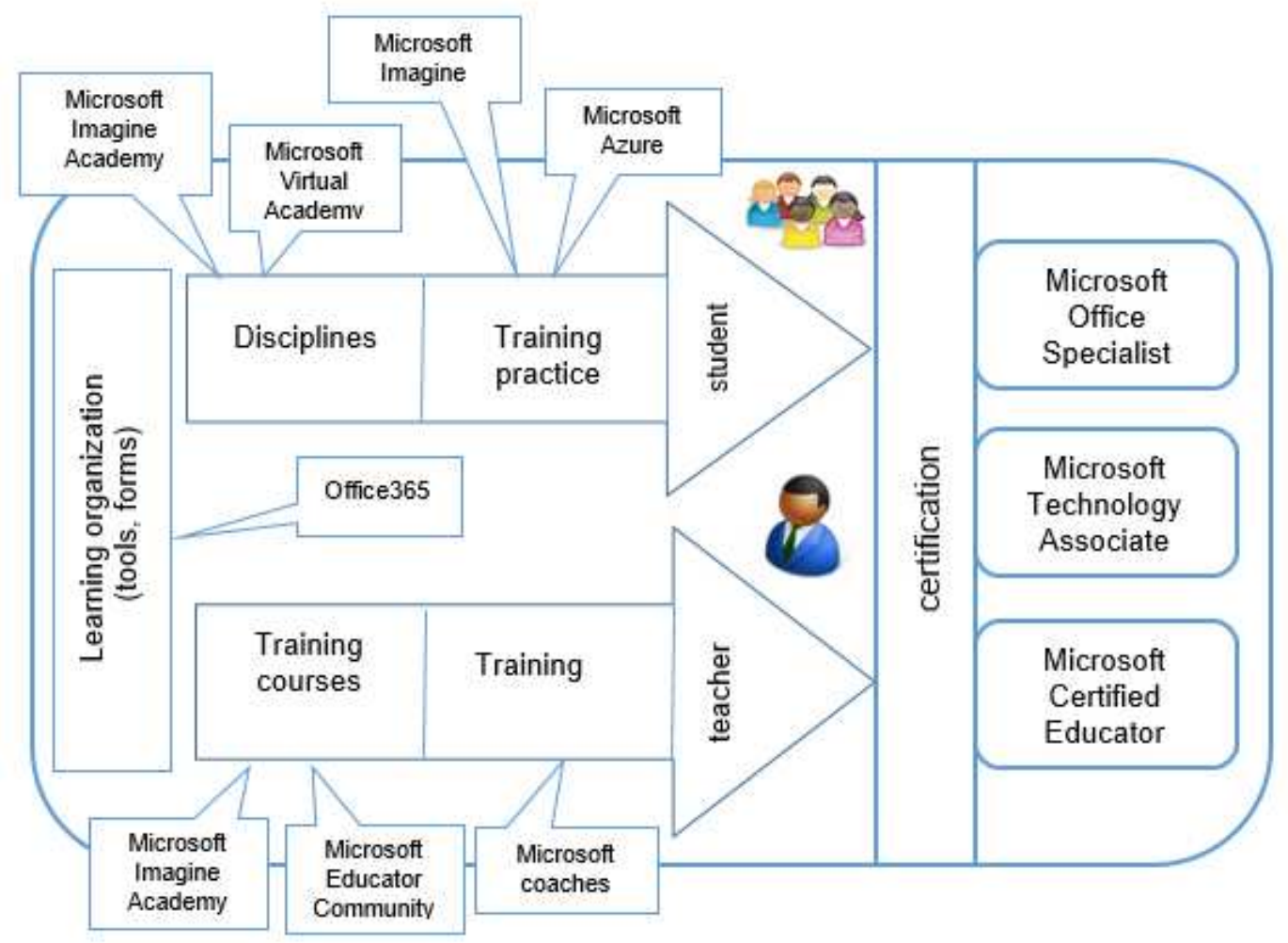

Figure 3. The model of integration of Microsoft resources and services into the academic process of NULES of Ukraine

Within the study of various disciplines and practical training, a teacher makes the curriculum in the academy which consists of a set of online courses. Students take these online courses during laboratory and independent works planned for the relevant discipline. The Academy Administrator creates curricula for groups of students, based on the lecturer's formal request, makes reports.

The evaluation system in the university involves the accumulation system of scores for various activities. Therefore, mastering these online courses within the discipline is assessed with a certain number of points and is obligatory for students. It is also possible for students themselves to choose courses in the academy and study without any additional motivation from the teacher. 
The study of a module dedicated to Excel spreadsheet consists of 8 laboratory works and independent work within the course "Information Technology". Course content is presented in the form of screen of eLearning course based on Moodle platform in the discipline "Information Technology" (fig. 5).

Independent work of students within the module includes doing the MIA courses «Get Started with Microsoft Excel 2016» and «Get Productive with Microsoft Excel 2016" (fig. 6), which are evaluated at 10 points within 100 scores for a module. Each student gets a certificate after completing the course.

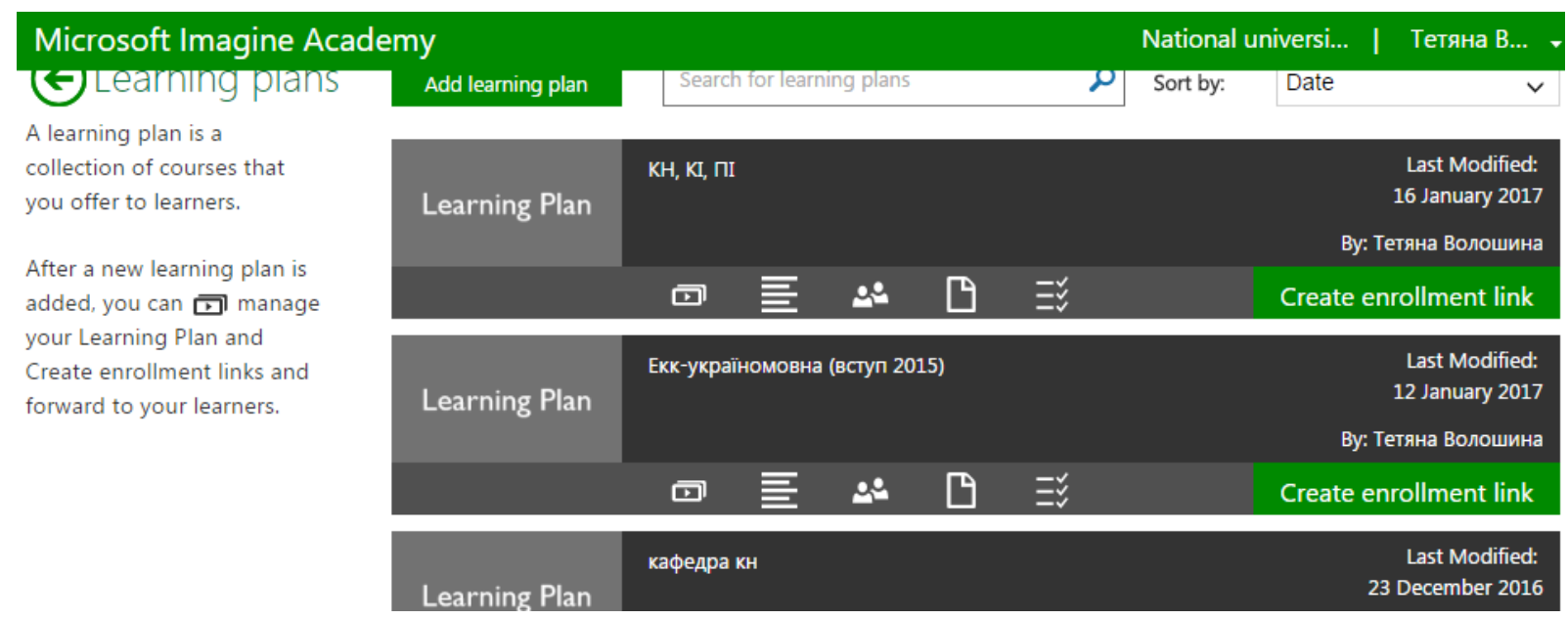

Figure 4.Curricula of faculty groups in Microsoft Imagine Academy
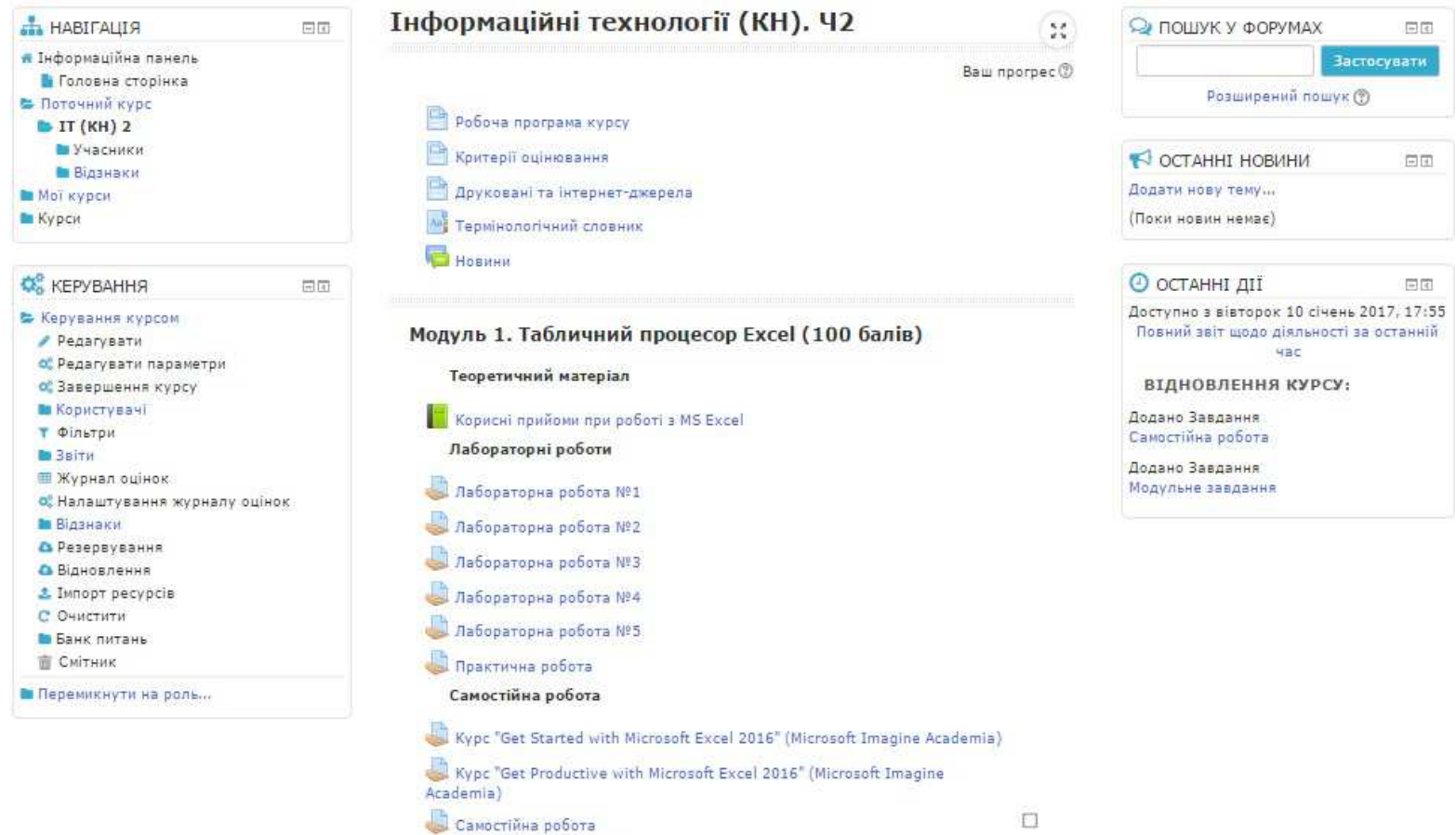

Figure 5. Page of e-course in the discipline "Informational technologies" 
In order to substantiate the impact of using the online courses of Microsoft Imagine Academy on the quality of training of future professionals the hypotheses $\mathrm{H}_{0}$ and $\mathrm{H}_{1}$ were checked.

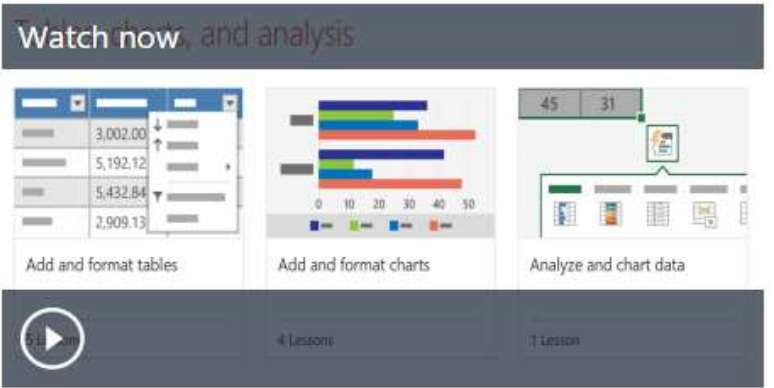

Add and Format Chart:

ᄃ Create charts

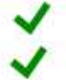

Figure 6. The page of on-line course «Get Productive with Microsoft Excel 2016» (Microsoft Imagine Academy)

The null hypothesis $\mathrm{H}_{0}$ proves that training of future IT professionals in the discipline "Information technology" using e-training course (ETC) and Microsoft Imagine Academy does not contribute to their progress. The alternative hypothesis $\mathrm{H}_{1}$ proves that training of future IT professionals in the discipline "Information technology" in accordance with the developed methods of using e-training course (ETC) and Microsoft Imagine Academy contributes to their progress.

The study of a module dedicated to Excel spreadsheet in the experimental groups was carried out according to the developed methods of integration of Microsoft Imagine Academy online courses into academic discipline, and in control groups-according to the traditional methods.

After completing the study of the module, the academic performance was measured by the results of tasks control, within 100-point scale.

Table 1

The results of knowledge control in academic groups

\begin{tabular}{|l|c|c|c|c|c|c|}
\hline \multirow{2}{*}{\multicolumn{1}{|c}{ Type of control }} & \multicolumn{2}{c|}{$\begin{array}{c}\text { The maximum } \\
\text { number of points }\end{array}$} & $\begin{array}{c}\text { Number of points, } \\
\text { the average }\end{array}$ & \multicolumn{2}{c|}{ Deviation } \\
\cline { 2 - 7 } & EG & CG & EG & CG & Points & \% \\
\hline $\begin{array}{l}\text { Independent work within MIA } \\
\text { courses }\end{array}$ & 20 & - & 20 & - & & \\
\hline Laboratory work & 50 & 50 & 33,01 & 31,5 & & \\
\hline $\begin{array}{l}\text { Independent work in solving } \\
\text { problems }\end{array}$ & - & 20 & & 16,02 & & \\
\hline Module task & 30 & 30 & 24,02 & 19,31 & 4,71 & 15,7 \\
\hline Total points & $\mathbf{1 0 0}$ & $\mathbf{1 0 0}$ & $\mathbf{7 7 , 0 3}$ & $\mathbf{6 6 , 8 3}$ & $\mathbf{1 0 , 2}$ & $\mathbf{1 0 , 2}$ \\
\hline
\end{tabular}


To make a decision the following calculations were done using Student's t-criterion

$$
t=\frac{\left|M_{1}-M_{2}\right|}{\sqrt{\frac{\left(N_{1}-1\right) \sigma_{1}^{2}+\left(N_{2}-1\right) \sigma_{2}^{2}}{N_{1}+N_{2}-2}\left(\frac{1}{N_{1}}+\frac{1}{N_{2}}\right)}}
$$

where $M_{1}, M_{2}$-arithmetic average, $\sigma_{1}, \sigma_{2}$-standard deviation, a $N_{1}, N_{2}$-dimensions.

The results of knowledge control are presented in Table 2.

Thus, each group received 2 sets of marks for performed module work, arithmetic average value of the average score is given in Table1. According to these sets standard deviation, coefficient of variation and the range of variation were determined by the formulas:

Standard deviation:

$$
\sigma=\sqrt{\sigma^{2}}
$$

according to the formula of calculating dispersion

$$
\sigma=\sqrt{\frac{1}{n} \sum_{i=1}^{n}\left(x_{i}-\bar{x}\right)^{2}}
$$

where $\mathrm{x}_{\mathrm{i}}$ - $\mathrm{i}$-th sample element, $\bar{x}$ - arithmetic average of a sample, $\mathrm{n}$ - sample volume.

The coefficient of variation is the ratio of standard deviation to the average arithmetic.

By means of MS Excel (function STDEV.S), standard deviation CG and EG, the coefficient of variation (standard deviation $=/$ GPA), the average deviation (function AVEDEV) are calculated.

Based on the analysis of table data ranking of researched factors was performed. The fact that the factor with the highest average point of an academic group got the highest rank was taken into the account while analising data. According to the rank calculated by means of MS Excel (function RANK.EQ), the coefficient of the weight of each factor was defined. The results of the calculations are presented in Table 2.

Table 2

The statistical treatment of results of the progress during the pedagogical experiment

\begin{tabular}{|c|c|c|}
\hline \multirow{2}{*}{ Characteristic } & \multicolumn{2}{|c|}{ Academic groups } \\
\cline { 2 - 3 } & CG & EG \\
\hline standard deviation & 10,76 & 0,56 \\
\hline coefficient of variation & 0,16 & 18,05 \\
\hline average deviation & 7,87 & 16 \\
\hline rank & 6 & 18,5 \\
\hline
\end{tabular}

Table 3

The data for calculating the Student's criterion

\begin{tabular}{|c|c|c|c|c|c|c|}
\hline \multirow{2}{*}{} & \multicolumn{2}{|c|}{ Sample } & \multicolumn{2}{c|}{ Deviation from average } & \multicolumn{2}{c|}{ Squared deviations } \\
\cline { 2 - 7 } & B1 & B2 & B1 & B2 & B1 & B2 \\
\hline Sum & 1203 & 2311 & 0,06 & 0,01 & 1964,5002 & 5324,967 \\
\hline Average & 66,83 & 77,03 & & & & \\
\hline
\end{tabular}

According to the data obtained let's calculate the empirical criterion. The average arithmetic of the sample of the experiment is $t_{\text {емр }}=2.7$. According to the table of limit values Student's-criterion on the significance level $\mathrm{p} \leq 0,01$ we determine confidence level tкp $=2.69$. Since 2.7> 2.69 and it is in the zone of significance, in terms of statistical hypotheses this 
statement is as follows: $\mathrm{H}_{0}$ hypothesis means that training of future IT professionals in the discipline "Information technology" using the developed methods of e-training course (ETC) and Microsoft Imagine Academy is insignificant and it is rejected; the alternative hypothesis $\mathrm{H}_{1}$ is accepted -in training of future IT professionals in the discipline "Information technology" in accordance with the developed methods of using e-training course (ETC) and Microsoft Imagine Academy contributes to their progress and it is significant.

Comparing the results of academic achievements of students in groups where MIA courses were used the progress has increased by almost $10.2 \%$. Results of similar research that was conducted within the disciplines "Programming", "Organization of data" showed the growth of progress in the control groups by $13 \%$ and $9.8 \%$ respectively.

In addition to the experimental study on the integration of Microsoft's academic resources, several experiments have been conducted at NULES of Ukraine on the use of services for communication and collaboration of Microsoft in the execution of project tasks by students.

As one of the general competences according to the standards of higher education in Ukraine in 2016 for the Information technology sphere is the ability to work as a team, the method of projects is used in training future IT specialists. Team work on the project is very effective and productive because it allows you to solve complex and bulky tasks that can not be performed efficiently and in time alone even by highly qualified specialists.

Microsoft Office 365 services are used for the organization of group work and establishing communication between students within the discipline "Information Technology" (NULES of Ukraine has an appropriate license agreement). The previous experiments described in [16] offered the implementation of a collective project for students on the equipment of the modern room at the faculty. For collaboration during the implementation of each phase of the project, students used the following services: cloud storage OneDrive, Web applications Microsoft: Word Online, PowerPoint Online, Excel Online. The result is the project portfolio, elements of which were posted in OneNote notebook according to the pattern offered by teachers. As a result while working on the project $27,77 \%$ of the students have developed the skills of effective communication, $22,22 \%$ - self-organization and leadership, 18,06\% - time management.

Another example of a group project for the students was to analyze the needs of specialists for the IT industry by searching online resources, tools, spreadsheets and Power BI and creating interactive presentations Sway. Cooperative collaboration required distribution of tasks among the members of an academic group, where everyone was responsible for their part of elucidating different issues for their further effective combination in order to achieve the goal. In order to do the task students used the site of the group on SharePoint, where each group stored its materials.

Another example of a group project task was to create sites using the platform Azure, which was carried out by students during practical training (http://nubip-3dprint.azurewebsites.net/).

The experimental groups that used Microsoft Azure platform and other services to perform individual work during practical training show more explicitly development of soft skills. This research was conducted on the basis of NULES of Ukraine and described in [17]. The research demonstrated the growth of the level of autonomy, which means the development of self-educational competence, motivation, teamwork skills, qualities of personal effectiveness, communication, ability to influence others, ability to see the final result of planned work and ability to manage the process.

While doing group projects, students of experimental groups that used services of O365for planning tasks, distribution of responsibilities, communication and collaboration have demonstrated more developed teamwork skills compared with the students of control 
groups who did not use these services. The survey conducted at the end of the presentation of projects has shown the following results of effective team work in indicators according to the 10-points scale (fig. 7).

With the aim of more active use of academic resources by teaching faculty in academic process it is necessary to conduct regular seminars, workshops, training courses on the use of ICT for organization of training. In NULES of Ukraine we have developed a professional development program for teaching staff called "The use of Microsoft cloud services in academic process" in cooperation with Microsoft Ukraine [18].

\section{Indicators of team work effectiveness}

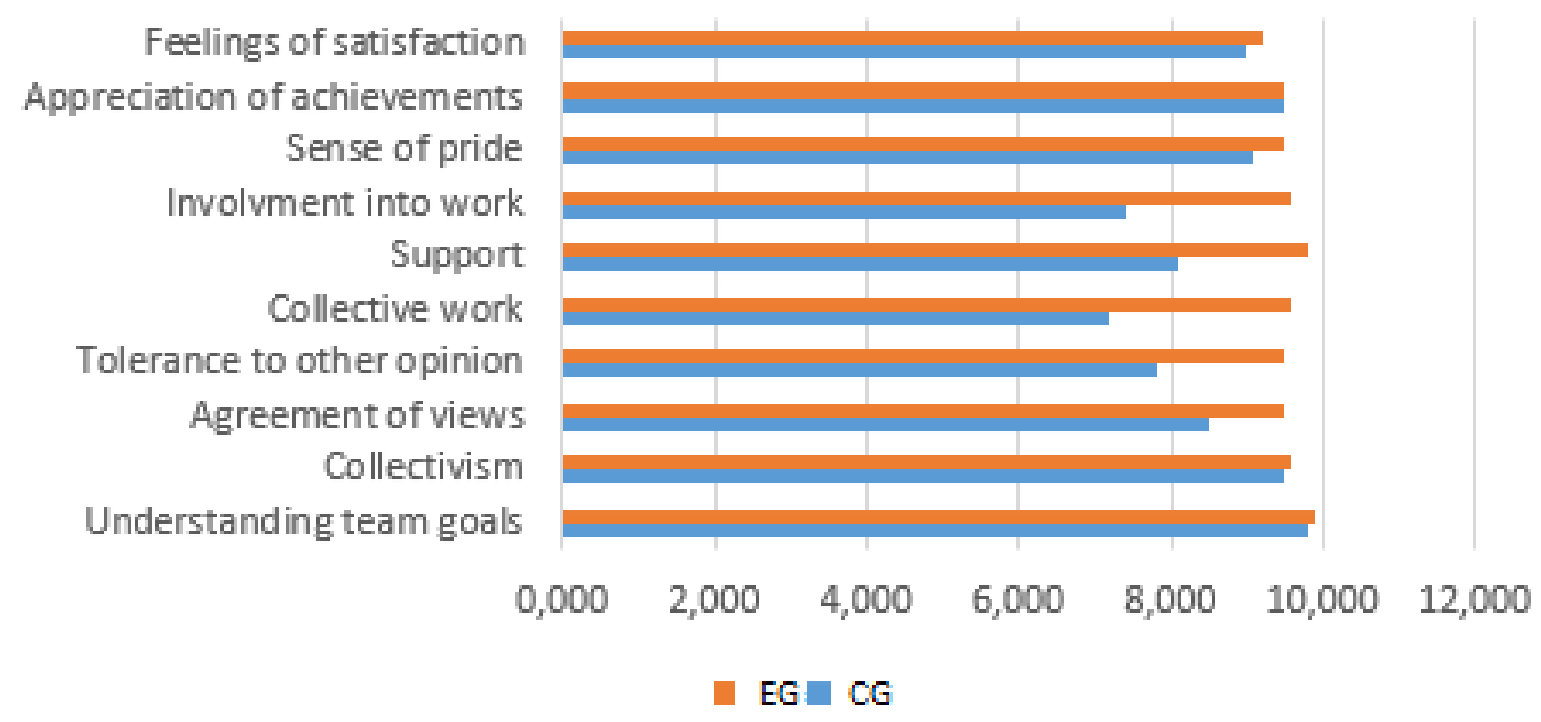

Figure 7. The results of the efficiency of students' teamwork

The course consisted of three modules: communication using cloud services; joint work with documents in the cloud O365; the use of cloud services and Microsoft technologies for learning.

Each module included classroom training as well as self-training based on online courses of Microsoft Educator Community (https://education.microsoft.com/).

Additionally, scientific and teaching staff were trained according to the curriculum of the course "Teaching Technology" which consists of 4 courses. These courses are designed to help teachers understand how information and communication technologies (ICT) can improve teaching, learning experience and allow students to gain skills of the 21 st century. More than 90 teaching staff of the University were trained and received Microsoft certificates.

\section{CONCLUSIONS AND PROSPECTS FOR FURTHER RESEARCH}

Having analysed the cooperation between IT-companies and technological higher educational institutions we have offered the model of cooperation on the example of collaboration with Microsoft based on several factors: 1) participation of companies in updating curricula and syllabi according to the competencies that IT-companies expect from a 
graduate; 2) qualification of the teaching staff; 3) availability of new technologies of ITcompanies to be learned and used by students and teachers.

Openness of IT-companies and cooperation with universities is the guarantee of the quality of IT-education. The cyclic process that begins with the formation of the requirements for professional competences of a future IT-specialist, continues with studying at the IT faculty which IT-industry provides with the latest technology, academic resources, the cloud platform for free access to technology, training of teaching staff in new technologies, and finishes with the certification of professionals and employment, leads to mutual improvement of efficiency of both IT-faculty and IT-industry, which is proved by the results of the experiments presented in this article. For the university such collaboration makes it possible to improve the quality indicators of training students that demonstrate more successful development of hard and soft competences: progress, motivation, level of independence, ability to work in a team.

For such IT companies as Microsoft the opportunity of cooperation with universities in specified areas determined by this article provides an opportunity to increase the number of certified users; appearance of certified professionals on the IT-market who are able to use Microsoft products in their professional activities; qualified teaching staff for Universities able to teach Microsoft technologies, thus, training a new generation of users.

\section{REFERENCES (TRANSLATED AND TRANSLITERATED)}

[1] N. I. Chukhray,Assessment and development of relations between business partners: monograph.2008, p. 360. (in Ukrainian)

[2] Y. Kondratenko, Analysis of peculiarities of innovative cooperation between academic institutions and IT companies in the directions of S2B and B2S, Technical reports. Lviv: Lviv Polytechnic National University, no. 1 (39), pp. 15-19, 2014. (in Ukrainian)

[3] H. Gogl, Knowledge Loves Company: Successful Models of Cooperation between Universities and Companies in Europe. 2009, p. 337. (in English)

[4] V. C. Kharchenko, V.V Sklyar, "Concept and models of interaction of university science and IT industry: S2B-B2S",v. 8-9, pp. 170-174, 2012. (in Ukrainian)

[5] V. C. Kharchenko, "University and Industry Cooperation: S2B-B2S", Cardboard, v. 3-4, pp. 43-49, 2014. (in Ukrainian)

[6] Ukrainian IT-market: results 2016 and perspectives 2017. [Online]. Available: https://dou.ua/lenta/articles/2016-summary.[Accessed: 08- May- 2017]. (in Ukrainian)

[7] CSR Practices in Ukraine 2016, Ed. Saprykina: CSR Development Center. 2016, p. 118. (in Ukrainian)

[8] Lviv IT Cluster [Online]. Available: http: //it-bpo.lviv.ua. [Accessed: 08- May- 2017]. (in Ukrainian)

[9] Educational IT programs for which it is not ashamed: IoT, Computer and Data Science in Ukrainian universities. [Online]. Available: https://dou.ua/lenta/articles/new-it-specializations. [Accessed: 08- May2017]. (in Ukrainian)

[10] Universities and business: international cooperation and perspectives for Ukraine. [Online]. Available: Mode of access: http://cost.ua/news/421-college-business-cooperation. [Accessed: 08- May- 2017]. (in Ukrainian)

[11] CHNU them. Fedkovych will collaborate with IT Company. [Online]. Available:http://studway.com.ua/chnu-fedkovicha.[Accessed: 08- May- 2017]. (in Ukrainian)

[12] T.O. Goncharenko, A.V. Tyutyunnik, "Using Microsoft IT Academy to create the ICT competence of students" Educational Discus, 7.3, pp. 28-37, 2014. (in Ukrainian)

[13] I.I. Suhonyak, A.M. Kovalchuk, A.O. Danilchenko, "Professional certification as a means of improving the level of practical training of students in IT specialties" [Electronic resource] // Information Technologies and Learning Tools, vol. 53, no. 3, pp. 109-122, 2002. [Online]. Available: http://journal.iitta.gov.ua/index.php/itlt/article/view/1424. [Accessed: 08- May- 2017]. (in Ukrainian)

[14] S.M. Tsirulnik, V.V. Zagorsky, A.O. Metelitsa, Problems and approaches of training IT industry. [Online]. 
Available:http://ir.lib.vntu.edu.ua/bitstream/handle/123456789/9371/27.pdf?sequence=1\&isAllowed=y.[ Accessed: 08- May- 2017]. (in Ukrainian)

[15] S. Martsenko, "Use of International Programs in the Study of Foreign Students". [Online]. Available: http://elartu.tntu.edu.ua/bitstream/123456789/8396/2/Conf_2014_Martsenko_SImplementation_of_international_42-43.pdf. [Accessed: 08- May- 2017]. (in Ukrainian)

[16] O. G. Kuzminska, T. V. Voloshyna, T. P. Sayapina, "Learning Technologies in an Innovative Oriented Educational Environment: A Competency Approach and Educational Communications" Scientific Bulletin of the National University of Bioresources and Natural Resources of Ukraine, Series Pedagogy. Psychology. Philosoph, Redcologist: Nikolayenko SM (Ed.) And others. K .: Millennium, vol. 253, no 2, pp. 50-64, 2016. (in Ukrainian)

[17] O. Glazunova, T. Voloshyna, "Hybrid Cloud-Oriented Educational Environment for Training Future IT Specialists: Information and Communication Technologies in Education" , Research, and Industrial Applications, Communications in Computer and Information Science, vol. 1614, pp. 157-167, 2016. [Online]. Available:http://ceur-ws.org/Vol-1614/paper_64.pdf. [Accessed: 08- May- 2017]. (in English)

[18] O. G. Glazunova, D.Yu. Kassatkin, O.G. Kuzminska, M.V. Mokriyev, A.I. Blozva, T.V. Voloshyna, T.S.Sayapina, Integration of educational resources and services of IT companies into the university's educational environment [collective monograph]. Kyiv: LLC "NVS Interservice", 2016, p. 285. (in Ukrainian)

Text of the article was accepted by Editorial Team 09.06.2017

\title{
РОЗВИТОК ПРОФЕСІЙНИХ І ОСОБИСТІСНИХ НАВИЧОК МАЙБУТНІХ ІТ- ФАХІВЦІВ У СПІВПРАЦІ $З$ ПРОВІДНИМИ ІТ-КОМПАНІЯМИ
}

\author{
Глазунова Олена Григорівна \\ доктор педагогічних наук, декан факультету інформаційних технологій \\ Національний університет біоресурсів і природокристування України, Київ, Україна \\ ORCID 0000-0002-0136-4936 \\ o-glazunova@nubip.edu.ua
}

Волошина Тетяна Володимирівна

ассистент кафедри інформаційних і дистанційних технологій

Національний університет біоресурсів і природокристування України, Київ, Україна

ORCID 0000-0001-6020-5233

t-voloshina@nubip.edu.ua

Дорош Наталія

Майкрософт Україна, Київ, Україна

ORCID 0000-0003-4934-6814

nadorosh@microsoft.com

\begin{abstract}
Анотація. Проблема технологічних університетів полягає в тому, що їх відставання від рівня розвитку ІТ-галузі може бути вирішене тільки за умови активної участі технологічних IT-компаній в підготовці майбутніх IT-професіоналів. Тільки співпраця між IT-компаніями та ІТ-факультетами може забезпечити ефективну підготовку майбутніх IT-фахівців. Університети вимагають доступу до нових технологій, 3 метою підтримки студентів i викладачів факультетів, щоб вони йшли в ногу з рівнем розвитку новітніх технологій. У статті проаналізовано напрями співробітництва ВН3 3 IT-компаніями. На прикладі інтеграції ресурсів і сервісів Microsoft у навчальне е-середовище університету виявлено, як впливає використання відповідних ресурсів на розвиток професійних навичок та «soft skills». Запропонована модель інтеграції ресурсів і сервісів Microsoft у навчальне есередовище.
\end{abstract}

Ключові слова: Т-освіта; ІТ-індустрія; онлайн курси; сервіси; ресурси; тверді навички; м'які навички. 


\title{
РАЗВИТИЕ ПРОФЕССИОНАЛЬНЫХ И ГИБКИХ НАВЫКОВ БУДУЩИХ ИТ- СПЕЦИАЛИСТОВ В СОТРУДНИЧЕСТВЕ С ЛИДИРУЮЩИМИ ИТ- КОМПАНИЯМИ
}

\author{
Глазунова Елена Григорьевна \\ доктор педагогических наук, декан факультета информационных технологий \\ Национальный университет биоресурсов и природопользования Украины, Киев, Украина \\ o-glazunova@nubip.edu.ua \\ ORCID 0000-0002-0136-4936 \\ Волошина Татьяна Владимировна \\ ассистент кафедры информационных и дистанционных технологий \\ Национальный университет биоресурсов и природопользования Украины, Киев, Украина \\ t-voloshina@nubip.edu.ua \\ ORCID 0000-0001-6020-5233 \\ Дорош Наталья \\ Майкрософт Украина, Киев, Украина \\ ORCID 0000-0003-4934-6814 \\ nadorosh@microsoft.com
}

\begin{abstract}
Аннотация. Проблема технологических университетов заключается в том, что отставание от уровня развития IT-отрасли может быть решено только при условии активного участия технологических ИТ-компаний в подготовке будущих IT-профессионалов. Только сотрудничество между ИТ-компаниями и ИТ-факультетами может обеспечить эффективную подготовку будущих ИТ-специалистов. Университеты требуют доступа к новым технологиям, с целью поддержки студентов и преподавателей факультетов, так чтобы они шли в ногу с уровнем развития технологий. В статье проанализированы направления сотрудничества ВУЗов и ИТ-компаний. На примере интеграции ресурсов и услуг Microsoft в учебный процесс университета определено как влияет использование соответствующих ресурсов на развитие профессиональных и «soft» навыков. Предлагается модель интеграции ресурсов и услуг Microsoft в учебную е-среду.
\end{abstract}

Ключевые слова: IT-образование; IT-индустрия; онлайн курсы; сервисы; ресурсы; твердые навыки; мягкие навыки.

\section{(c) BY-NC-SA}

This work is licensed under Creative Commons Attribution-NonCommercial-ShareAlike 4.0 International License. 